\title{
Metaphysics after Aquinas
}

\author{
Moses Aaron T. Angeles
}

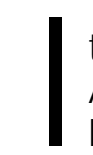

$\mathrm{t}$ is interesting to note that after the death of St. Thomas his mentor, St.

Albert the Great, remarked that his student put up an end to everybody's

labor, not only in their own time, but even right up to the end of time. This was reported to us by a certain Bartholomew of Capua, protonotary from the Kingdom of Sicily, who was a witness of St. Thomas' canonization process. After the sudden demise of Thomas, Albert, already advanced in age, has assumed the task of defending the integrity of his student as a theologian and philosopher. On his return to Cologne, he wanted that all the works of Thomas read to him in set order, and he concluded his encomia saying that "Brother Thomas had in his writings put an end to everybody's labors right up to the end of the world, and that from now on all further work would be without purpose." 1 Certainly modern readers would question such an assertion. Now that every ideology and systems of thought are under the suspicious eyes of postmodern thinkers, care must be exercised in proclaiming something as final and definite. No wonder such a statement was rarely uttered even within the ranks of the D ominican Friars.

We may very well remember Martin Heidegger's insinuation that Truth is always an unconcealment and concealment at the same time - A letheia which is of course again bound by poiesis - a bringing-forth. ${ }^{2}$ Imposing boundaries on Truth is certainly an act that violates the very nature and essence of Truth. In the same sense, once we have put an end to metaphysical reasoning by proclaiming a thinker as the repository of learning we are stifling discourse - thus the end of knowledge. Similar to the Platonic domain of the perfect being, Thomistic doctrine would stand determined and immutable for all time, ever aloof and invincible from the changing tides of human intellection. Metaphysics then, together with other Thomistic principles and doctrines, would have its history already completed. It will be a being in the past, and consequently, will have no future. Fr. Owens puts this most emphatically: "The sum total of human intellectual achievement would have been already attained and would remain complete for admiration and respect

\footnotetext{
${ }^{1}$ Acta Sanctorum (March), I: 712. Cf. Herbert Thurston and D onald Attwater eds., Butler's L ives of the Saints. V olume 1: January-M arch (Maryland: Christian Classics, 1996), 509-513.

${ }^{2}$ Cf. Martin Heidegger, The Question Conœrning Technology and 0 ther Essays, trans. by William Lovitt (New York and London: G arland Publishing, Inc., 1977), 12-13.
} 


\section{METAPHYSICS AFTER AQUINAS}

but not open to progress or change." 3 Indeed he was very insistent saying: "History denies emphatically that St. Thomas in his writings has put an end to all intellectual labors." 4 Indeed, after the too conclusive remarks of St. Albert, a new breed of metaphysicians are born arguing for or against Aquinas, and most certainly, even beyond the domain of the Angelic Doctor's structure of reasoning.

Metaphysical Reasoning does not end in St. Thomas, rather, it blossomed to such an extent that may even proved unimaginable even for Aquinas. To strengthen this contention, Fr. O wens enumerated the followers of Aquinas immediately after his death. He mentions Henry of $G$ hent, $G$ iles of Rome, and Blessed John D uns Scotus. In truth, they swore allegiance to the philosophical and theological doctrines of the Angelic Doctor, but in reality, they have diverging interpretations of him.

Modernity came and Rene D escartes, armed with his Methodic D oubt, seeks to re-evaluate knowledge by destroying its foundations. Metaphysical Reasoning was never the same after the unwavering attack of Modernity's most influential thinker. Christian Wolff then arrived to the rescue, perhaps with compassion to the victim of D escartes, systematizing metaphysics and calling it O ntology. He elevated it to a level that cannot be reached unless by those who dispose themselves to higher abstract thinking. Then comes Immanuel Kant who blows apart the Wolffian structure of Metaphysics equipped with his three Critiques. The noumenon can never be known, declared Kant, no matter how hard we try, only the phenomenon, the thing as it appears to the consciousness, can be known. G.W.F. Hegel came, seeking to salvage what was left after Kant's critique, idealized Metaphysics. He elevated it to such a height so that Kant may never again violate her. After which the Logical Positivists convened forming the infamous Vienna Circle whose only reason for being is the destruction of metaphysics.

These things happen and it proclaims a single truth - Metaphysics does not end in St. Thomas. Rather, Thomistic Metaphysics must be open to infinite possibilities, "it is of such character that it can never be closed and final." 5 "It is a doctrine," proclaims Owens, "that has to be re-thought and relived through the changing problems and different outlook of each succeeding generations." 6 He even goes on to say that the fundamental challenge to every metaphysician is to make metaphysics relevant to contemporary culture. "The problem is to examine what role metaphysics is able to play in the world as we know it and as you, for instance, in your university are working toward shaping it, and what need there is for the presence and activity and general acceptance of metaphysics in such a world." 7 In a similar vein, Taylor underscored that

${ }^{3}$ Joseph O wens, C.Ss.R., St. Thomas and the F uture of M etaphysics (Milwaukee: Marquette University Press, 1973), 2.

${ }^{4}$ Ibid., 3.

${ }^{5}$ Ibid., 6.

${ }^{6}$ Ibid.

${ }^{7}$ Ibid., 12 
"metaphysics is an attempt to find the right intellectual attitude toward ultimate reality." 8

\section{Aquinas and the Timeless Quest for Being}

First and foremost we have to get a good grasp of what metaphysics is all about. So we have to ask, "What is Metaphysics?" No one will surely doubt that any person studying or writing something about metaphysics is constantly asked about this most simple and obvious question yet the most difficult and perplexing to define. We find ourselves trying to answer the question, but in the end, we are embarrassed to affirm that we really know nothing about it. It is a very common practice to answer the question by simply discussing how Plato, for example, explained it, through the level of pure forms and the dialectics of Idea. Any student of philosophy would readily define it as the science of being, or the study of being in general. At first blush, the definition seems to answer our inquiry. For sure, metaphysics speaks about those things that are beyond this world, that is, beyond the realm of the five external senses. And more so, is not this the very etymological definition of metaphysics? But in truth, such a definition of metaphysics as the science of being only gives us more problems than answers. What is being? Being, as Heidegger puts it, is the most elusive of questions. Being is the most evident and at the same time the most concealed. Another question pops, how scientific is our investigation on it?

Being was interpreted in many ways. Plato understood it on the level of Pure Forms while Aristotle defined it in terms of hylemorphism. D escartes on the other hand departed from his Cogito, while Locke, though proclaiming himself an empiricist, clings to the idea of the Substratum. The list goes on and on but there is one common feature about them, that is, Being is transformed and understood in many ways. No wonder, Heidegger's critique about it was so substantial that he argues of raising once more the problem of Being Fraglichk eit. 9

Going back to our original problem - metaphysics that is - Aristotle, unlike the many thinkers who came before him, provided a clear cut definition of what metaphysics is all about. He argued that metaphysics, which he also equated with wisdom, is the science of the ultimate causes and principles. And I quote directly from The Philosopher himself "All men suppose what is called wisdom to deal with the first causes and principles of things; so that, as has been said before, the man of experience is thought to be wiser than the possessors of any sense-perception whatever, the artist wiser than the men of experience, the master-worker than the mechanic, and the theoretical kinds of

\footnotetext{
${ }^{9}$ Heidegger insists that Being was forgotten in the many ontical transformations of Being. He underscored the fact that we have to raise once more the problem of Being and discover it devoid of onto-theo-logical notions. See Martin Heidegger, Being and Time, trans. by John Macquarrie (London: Blackwell Publishers, 1977).
}

${ }^{8}$ A.E. Taylor, E lements of Metaphysics, 13th edition (London: Methuen and Co., 1952), xi-xii. 


\section{METAPHYSICS AFTER AQUINAS}

knowledge to be more of the nature of wisdom than the productive. Clearly then Wisdom is knowledge about certain principles and causes." 10 Owens pointed out that such an idea has not passed unchallenged. Certainly, "for some, metaphysics does not come under the designation of 'science' at all; rather, like philosophy in general, it is explicitly set apart from and contrasted with science." 11 Well, we may have to question the integrity of metaphysics as a science, however, we cannot deny the fact that Aristotle's metaphysics insists that we should possess a right intellectual attitude towards ultimate reality. More so, metaphysical reasoning directs the mind to think and contemplate in the highest level. $\mathrm{O}$ wens puts this in a more fashionable manner saying:

Knowledge of such causes (the ultimate cause of the universe) was therefore the highest and ultimate knowledge possible. Contemplation of such substances, the pursuit of metaphysics, was the supreme goal of human life, both social and individual. It was indeed attainable only by men only in rare moments and for brief intervals; but it was worth subordinating to its attainment all individual and social activity. It was the supreme end of human life. It was life at its highest and best. ${ }^{12}$

The integrity of metaphysics in this Aristotelian perspective is easy to comprehend. It is the science that provides knowledge of things that no other human discipline could reach. "To investigate all the species of being qua being is the work of a science which is generally one and to investigate the several species is the work of the specific parts of the sciences. ${ }^{13}$ No wonder, for Aristotle metaphysics is indeed the queen of the sciences.

The metaphysicians during the medieval ages are most convinced that metaphysics is indeed the science of being qua being, but there is difficulty in equating that science as the science of spiritual beings. The problem is too complicated solve: juxtaposing Aristotle's metaphysics, the influence of the great Doctor St. Augustine, and the most revered of books: The Sacred Scriptures. The Divine Nature could not be the object of any human science, not even the queen of the sciences. Therefore G od is not looked upon as the subject of metaphysics. This traditional stance is of course summarized in the works of St. Bonaventure - a friend of Thomas and a staunch defender of the Holy Father Augustine. Indeed, we can hear his outcry even beyond the grave: "The followers of Aristotle are the followers of darkness." 14

\footnotetext{
${ }^{10}$ Aristotle, Metaphysics trans. by W.D. Ross, in The Basic Works of Anistolle ed. by Richard McKeon (New York: Random House, 1941), 690-691.

${ }^{11}$ Owens, op it, 14.

${ }^{12}$ Ibid, 16-17.

${ }^{13}$ Aristotle, qp at, 733.

${ }^{14}$ Cf. St. Bonaventure, TheWorks of Bonaventure Cdlations on theSix Days, trans. by Jose de Vinck (New Jersey: St. Anthony G uild Press, 1970), VI: 2-5.
} 
But of course, as we are all aware of, Thomas was successful in his synthesis of Christian doctrine and the pagan philosopher. "All men by nature desire to know"15 and most certainly, Thomas is very much convinced, man is thirsting to know, and not just believe, things beyond the sensible world - and this includes God and other spiritual beings. Surely, these are truths proposed to one's faith, but their most peculiar significance at once places these subjects as primary objects for intellectual inquiry. The mystery behind the Divine should not deter us from asking, it is an avenue of invitation to penetrate into these mysteries of faith.

\section{The Conflicting Interpretations of Thomistic Metaphysics}

If metaphysics directs the mind to the highest and the best, as Aristotle argued, what then has the Angelic Doctor offer to attain this end? Contrary to the remarks of St. Albert, "no completely developed and finished metaphysics is to be expected in the writings of the great thirteenth century doctor. His metaphysical teachings are for the most part scattered throughout theological treatises or Aristotelian and other commentaries and brought in only as occasion demanded." 16

To begin with, the metaphysical procedure found in Aquinas proclaims itself a science. Aquinas asserted: "Theology or divine science deals with all these (the practical sciences and the speculative sciences). It is called by another name 'metaphysics', that is to say, 'transphysics', because in the order of knowing it comes after physics for us who must rise from sensible things to what is beyond the sensible." 17 Commenting on the passage, $\mathrm{O}$ wens said: "It starts from what is evident in everyone's immediate experience of the tangible world, in fact from what is most self-evident of all, namely that something exists. Into this basic and utterly self-evident premise does it ultimately resolve all its conclusions." 18 From this standpoint, Aquinas is indeed proceeding according to the rigorous technique of propter quid, that is, the most truly scientific type of thinking possible. ${ }^{19}$ It is very explicit then that the metaphysical doctrine of Aquinas purports to a scientific understanding of Being. In fact, Aquinas' fundamental aim is to have a knowledge of $\mathrm{G}$ od and the spiritual substances. It comports the thinker to "a general science that pervades all the objects of human knowledge." 20

Here is the problem, from the basic standpoint of Aquinas, certain difficulties arise from his interpreters. Several schools of thought within the ambit of Thomism itself arise from the Thomistic Revival of Leo XIII's A eterni

\footnotetext{
${ }^{15}$ Aristotle, op. cit., 689.

${ }^{16}$ O wens, op. cit., 30-31.

17 St. Thomas Aquinas, Commentary on the DE TRINITA TE of Boethius, trans. by Armand Maurer (Toronto: The Pontifical Medieval Institute, 1958), 7-8.

${ }^{18}$ O wens, op. cit., 32.

${ }^{19}$ Ibid.

${ }^{20}$ Ibid., 33.
} 


\section{METAPHYSICS AFTER AQUINAS}

Patris. Knasas ${ }^{21}$ enumerated and discussed in detail these schools of thought. The first school, Aristotelian Thomism, tended to interpret the metaphysics of Aquinas as a sort of medieval Aristotelianism explaining it in accordance to the principle of act and potency, that is, in relation to the long tradition of Thomistic interpretations. Along these lines, studies emerged proposing the analogy of proper proportionality as the key to understanding the Thomistic metaphysical procedure. ${ }^{22}$ It has also become apparent that there is a need to go beyond the framework of Aristotle, though the Aristotelian Thomists insist that they should remain within the ambit of the traditional commentators. There are even scholars who argue for a Platonic and Neo-Platonic doctrine of Participation the basis for a more profound understanding of Aquinas' metaphysics.

The second camp of Neo-Thomism is Existential Thomism. Certainly, it has nothing to do to the Existentialism proposed by Kierkegaard and his minions, rather, the term existential "we mean to draw attention to its 'act' or 'attribute' understanding of what is meant by the 'existence' of any individual thing." We should remember that Aquinas rarely uses the term "existence," rather he uses "esse". The position of the Existential Thomist is that "something is called a being in virtue of possessing its esse or actus essendi. Consequently, a being is a 'quasi habens esse.' A being is 'as if a haver, or possessor, of esse." They pointed out that Aquinas insists that to understand esse is to understand as "act or actuality of all acts and the perfection of all perfections. But as an act or actuality, substantial and accidental forms are distinct items composed with another item that is in potency to the act." "In sum, it is not so much that Aquinas disagrees with the fact-sense of the thing's existence, but rather that Aquinas insists that the fact-sense be deepened to include the act in virtue in which the thing is a fact. A thing is a fact in virtue of its actus essendi." This implies then that existence subsists in one being alone, and is participated analogously as act by potency in all other things. The being of a thing then, according to Existentialist Thomists, is originally grasped and attained by the human intellect not through any act of conceptualization, but only through the act of judging." 23 Accordingly, what is grasped in the judgment and later conceptualized and gradually seen in its relation to the essence as act to potency. "What is immediately and directly known by the human intellect is the individual thing in the sensible world. Such things are thereby judged to exist in themselves, that is in reality outside the mind. But by reflection the intellect sees those same things existing in its own cognition.

${ }^{21}$ Lectures 3, 4, 5, 6, and 7. These are unpublished lectures of Dr. John Knasas, professor of Philosophy at the University of St. Thomas, Houston Texas. These lectures were delivered when he came to Manila in January 2007 at the G raduate School of the University of Santo Tomas.

${ }^{22}$ O wens, op. cit., 34 .

${ }^{23}$ A thorough discussion of this could be found in Etienne Gilson's Thomist Realism and the Critique of Knowledge, trans. by Mark Wauck (San Francisco: Ignatius Press, 1986). 
The thing itself, or if you wish, essence or nature, remains exactly the same; but its existence in each two cases are different." 24

The Transcendental Thomists on the other hand shifted the paradigms of metaphysical reasoning. Knasas explains: "A refrain among Transcendental Thomists is: 'You can know the finite only if you know the infinite, you can know the limited only if you know the unlimited.' Both the finite and the limited appear only in juxtaposition to the infinite and the unlimited. The intellect's dynamism to infinite Being is what sets up that juxtaposition." And this is the very reason why Transcendental Thomism is the preferred philosophical instrument of theologians.

Knasas concluded with Pope John Paul II's Fides \& Ratia To the disappointment of the Aristotelian Thomist and the Transcendental Thomist, the Supreme Pontiff exhorts the faithful that "wonder begins in philosophy, the stirring and ceaseless effort of the human mind, a seed of desire and nostalgia for $\mathrm{G}$ od in the far reaches of the human heart, the search for truth deeply rooted in human nature, the human being's characteristic openness to the universal and the transcendent and the religious impulse innate in every person." These things occur within the orbit of the experiential - within the a posteion. Moreover, the pope was very adamant that with the aid of faith, the intelectus fide, "the value of metaphysics, or philosophy of being, that is based on the act of being." To quote the pope: "If the intelletus fide wishes to integrate all the wealth of the theological tradition, it must turn to the philosophy of being, which should be able to propose anew the problem of being."

\section{Conclusion}

Obviously, Thomistic metaphysics has a very difficult role to play. It has to learn the general language of various existing forms of science which it constantly encounters, to dialogue with them, to penetrate into the very nature of their thinking, and to keep updated with progressive changes and development. In this respect, we will never see the activity of Thomistic metaphysics already concluded. Suffice it to say, every new problem gives birth to a new interpretation.

Far from the loving remarks of St. Albert, metaphysical reasoning does not end in St. Thomas Aquinas. History attests that the mind is open to infinite possibilities, for indeed, what makes philosophy interesting is its stigma for asking questions again and again. St. Thomas for sure never affirmed that his work is the summation of everything that can be learned, rather, his metaphysics is one man's authentic searching for the Truth, an endless quest for God. Certainly, the greatness of Aquinas does not lie in the answers that he offered, rather, in the questions that he formulated that arouses the generation of thinkers who came after him. For sure, "The metaphysical principles of St. Thomas Aquinas open the way to the highest natural activity

\footnotetext{
${ }^{24}$ Owens, qp at, 39-40.
} 
of the highest natural faculty. By emphasizing this tribute to his life-long work we today do our modest part in continuing to ensure for his thought the preeminent place envisaged by St. Albert, and in so doing, as we contemplate the worth of the metaphysical inheritance which he has left us, we humbly return our thanks for the highest natural gift of God to men." 25

F aculty of A rts and L etters, U niversity of Santo T omas, Philippines

\section{References Cited}

Aquinas, Thomas, Commentary on the DE TRINITA TE of Boethius, trans. by Armand Maurer (Toronto: The Pontifical Medieval Institute, 1958). , On Truth, trans. by James V. McG lynne (Indianapolis: Hackett Publishing Company, 1995). , Summa Theologica, trans. by The Fathers of the English D ominican Province (Maryland: Christian Classics, 1981).

Aristotle, The Basic W ork s of A ristotle, trans. by Ross, W.D. and ed. by Richard McKeon (New York: Random House, 1941).

Bonaventure, St., The W orks of Bonaventure: Collations on the Six D ays, trans. by Jose de Vinck (New Jersey: St. Anthony Guild Press, 1970).

Catan, John R. ed., St. Thomas A quinas on the E x istence of $\mathrm{G}$ od: The C ollected Papers of Joseph 0 wens (Albany: State University of New Y ork Press, 1980).

Copleston, Frederick, A quinas (New Y ork: Penguin Books, 1955).

Gilson, Etienne, The Christian Philosophy of St. Thomas A quinas, trans. by L.K. Shook (Notre D ame: University of Notre D ame Press, 1994). , Thomist R ealism and the Critique of Knowledge, trans. by Mark Wauck (San Francisco: Ignatius Press, 1986).

Glenn, Paul, 0 ntology, (London: Herder Books, 1937).

Heidegger, Martin, Being and Time, trans. by John Macquarrie (London: Blackwell Publishers, 1977). , The Q uestion Concerning Technology and 0 ther E ssays, trans. by William Lovitt (New York and London: G arland Publishing, Inc., 1977).

John Paul II, Pope, Fides et Ratio (Manila: St. Paul's Publication, 1998).

Kretzmann, Norman and Eleonore Stump eds., The Cambridge Companion to A quinas (Cambridge: Cambridge University Press, 1993).

McBrien, Richard, Catholicism (London: G eoffrey Chapman, 1994).

Mensch, James Richard, Knowing and Being: A Postmodern Reversal (Pennsylvania: The Pennsylvania State University Press, 1996).

O wens, Joseph, St. Thomas and the F uture of Mataphysics (Milwaukee: Marquette University Press, 1973).

Rengers, Christopher, The 33 D octors of the Church (Rockford: Tan Books and Publishers, 2000).

Taylor, A.E., Elements of Metaphysics, 13th edition (London: Methuen and Co., 1952).

\footnotetext{
${ }^{25}$ Owens, op. cit., 60-61.
} 
Thurston, Herbert and D onald Attwater eds., Butler's L ives of the Saints, Volume 1: January-March (Maryland: Christian Classics, 1996).

Torrell, Jean-Pierre, Saint Thomas A quinas, tran. by Robert Royal (Washington: The Catholic University of America Press, 1996). 